Journal of

Ecology 2003

91, 951-965

\title{
Plant zonation in irregularly flooded salt marshes: relative importance of stress tolerance and biological interactions
}

\author{
CÉSAR S. B. COSTA, JULIANO C. MARANGONI and \\ ADRIANA M. G. AZEVEDO \\ Departamento de Oceanografia, Fundação Universidade Federal do Rio Grande (FURG), CP 474, Rio Grande, RS, \\ 96200-901, Brazil
}

\begin{abstract}
Summary
1 Most studies of salt marsh plant zonation have been at middle to high latitudes of the northern hemisphere, in euhaline or periodically hypersaline marshes with regular tides. In this study, we examined plant zonation in an irregularly flooded marsh in southern Brazil. Pore water characteristics were compared in four vegetation zones across a marsh elevation gradient. Reciprocal transplants between vegetation zones and removal experiments were performed to examine species interactions in low and mid marshes.

2 There was no distinctive gradient of physical stress across the elevation of irregularly flooded low and mid marshes. Moreover, the three dominant plants, Spartina alterniflora, Spartina densiflora and Scirpus maritimus, were able to grow across the entire elevation gradient, i.e. within zones normally occupied by the other species. The only exception was Spartina alterniflora, which was strongly limited by selective herbivory by the crab Chasmagnathus granulata in the Scirpus maritimus zone.

3 Although intra- and interspecific competition reduced growth of all three species, no competitive hierarchy was found in any vegetation zone.

4 These results suggest that, as in tidal marshes of the north hemisphere, competition is important in structuring salt marsh plant communities. In contrast, however, plant zonation in irregularly flooded marshes cannot be explained by displacement of competitive subordinates to physically stressful habitats. The roles of founder effects and selective herbivory in such marshes therefore merits further investigation.
\end{abstract}

Key-words: competition, Grapsidae crab, herbivory, non-tidal marsh

Journal of Ecology (2003) 91, 951-965

\section{Introduction}

Well-developed coastal salt marshes display a zonation of plant species parallel to the shore. Several studies of salt marsh zonation and community structure have concentrated on the role of the physico-chemical effects of inundation with seawater (Ranwell 1974; Pielou \& Routledge 1976; Jefferies 1977; Jefferies et al. 1979; Vince \& Snow 1984; Rozema et al. 1988; Zedler et al. 1999; Rogel et al. 2000). There can be no doubt that elevation and salinity are major determinants of distribution per se and also that physico-chemical factors affect the outcome of any biotic interactions (Pennings \& Callaway 1992; Callaway \& Pennings 2000; Davy et al. 2000; Emery et al. 2001). Understanding zonation requires consideration of a realistic range of environmental
Correspondence: C. S. B. Costa (fax +55 532336602; e-mail docosta@furg.br). variability and evaluation of biotic interactions and is therefore likely to involve field experiments.

Most experimental field studies of zonation in salt marsh plants have been conducted at middle and high latitudes of the northern hemisphere and in regularly tidal marshes (Jefferies 1977; Snow \& Vince 1984; Scholten et al. 1987; Rozema et al. 1988; Pennings \& Bertness 1999; van Wijnen \& Bakker 1999; Castillo et al. 2000; Davy et al. 2000; Pennings \& Bertness 2001; Pennings \& Moore 2001). These studies point to trade-offs between stress tolerance and competitive ability and a competitive displacement of subordinate species to physically stressful habitats (Snow \& Vince 1984; Rozema et al. 1988; Bertness 1991a, 1991b; Pennings \& Callaway 1992; Bertness \& Callaway 1994; Bertness 1999; Pennings \& Moore 2001). Nutrient availability (Jefferies 1977; Rozema et al. 1988; Levine et al. 1998; van Wijnen \& Bakker 1999; Emery et al. 2001), perturbation by wrack (Bertness \& Ellison 1987; Bertness 1999), ice damage (Pennings \& Bertness 
952

C. S. B. Costa,

J. C. Marangoni \&

A. M. G. Azevedo
2001) and herbivory (Cargill \& Jefferies 1984; Iribarne et al. 1997; Taylor et al. 1997; Bortolus \& Iribarne 1999), as well as positive interactions (e.g. plant cover alleviating saline stress) (Bertness \& Callaway 1994; Bertness \& Leonard 1997; Hacker \& Bertness 1999; Callaway \& Pennings 2000), may also be locally important in shaping salt marsh plant communities.

It is unclear how far this can be extrapolated to microtidal and irregularly flooded salt marshes. In these ecosystems flooding patterns are primarily driven by variation in rainfall and wind direction (Eleuterius \& Eleuterius 1979; Stout 1984; Costa et al. 1988; Christian et al. 1990; Wang 1997; Holm et al. 2000; Möller et al. 2001), and both salinity and the timing and duration of flooding are thus less predictable. In contrast to tidal salt marshes, where dominant species tend to be restricted to specific zones with little habitat overlap (Pielou \& Routledge 1976; Russell et al. 1985; Bertness 1999), irregularly flooded salt marshes have perennial dominants growing across wide ranges of salinity and water level, with considerable habitat overlap (Ranwell 1974; Eleuterius \& Eleuterius 1979; Odum 1988; Baldwin \& Mendelssohn 1998).

Salt marshes occupy $70 \mathrm{~km}^{2}$ of the intertidal zone of the estuarine region of Patos Lagoon in southern Brazil (Costa et al. 1997). Diurnal tidal range is very small (astronomical tides, less than $0.5 \mathrm{~m}$ ) and fluctuations of water level and salinity are irregular (Costa et al. 1988; Möller et al. 2001). The native grasses Spartina alterniflora Lois. and Spartina densiflora Brong. tend to dominate mesohaline low- (between $-50 \mathrm{~cm}$ and $+10 \mathrm{~cm}$ MWL; mean water level of the estuary) and mid marshes (+10 to $+30 \mathrm{~cm}$ MWL), respectively (Silva et al. 1993; Costa 1997a, 1997b), while highly productive stands of Scirpus maritimus L. may opportunistically dominate transitional areas between low and mid marshes (Costa 1998). These dominant species occur over a wide vertical range with a high degree of overlap (Costa 1997a), and monospecific stands of all three can often be found at the same tidal level. The local occurrence of such discrete patches suggests that interspecific competition plays an important role in the structure and composition of these communities. The herbivorous Grapsidae crab Chasmagnathus granulata Dana, 1851, which is one of the most abundant macroinvertebrates in the salt marshes along the coasts of southern Brazil and northeast Argentina, is found at high density in the intertidal zone (D'Incao et al. 1990; Copertino et al. 1997) feeding on Spartina spp. (D'Incao et al. 1990; Iribarne et al. 1997; Bortolus \& Iribarne 1999; Bortolus et al. 2002). The relative importance of stress tolerance, competition and herbivory in the distribution patterns of these dominant plants, however, has yet to be examined. Such ecological information is particularly important because $S$. densiflora has been introduced unintentionally to the coasts of California (Kittelson \& Boyd 1997) and southwestern Spain (Figueroa \& Castellanos 1988; Castillo et al. 2000), where it has been displacing indigenous low marsh dominants.
We use methods identical to those applied in the north hemisphere (reciprocal transplantation between vegetated zones and removal of neighbours), to test the hypotheses that: (i) distributions of the dominant species (Spartina densiflora, Spartina alterniflora and Scirpus maritimus) on irregularly flooded low to mid marsh zones in southern Brazil are related to their competitive performance; and (ii) stress tolerance has a minor role in zonation of marshes with poorly predictable hydrology. We therefore tested the applicability of community structuring rules based on work in northern-hemisphere salt marshes to marshes with no distinct tidal regime. We also examined whether selective grazing by Chasmagnathus granulata could affect the performance of dominant plants and thus community structure.

\section{Materials and methods}

\section{THE STUDY AREA}

A c. $10000 \mathrm{~km}^{2}$ Patos Lagoon, located in southern Brazil $\left(30-32^{\circ} \mathrm{S}\right)$, is the word's largest choked lagoon (i.e. characterized by a single, narrow, but permanently open, entrance channel). It receives runoff from the $5500 \mathrm{~km}^{2}$ Mirim Lagoon near the Brazil-Uruguay border (Möller et al. 2001; Seeliger \& Costa 2002), forming a large lagoon complex that only exchanges water with the Atlantic Ocean through the Patos Lagoon estuary, an inlet $20 \mathrm{~km}$ long and $0.5-3.0 \mathrm{~km}$ wide.

The study site was located on the north-west side of Pólvora Island $\left(32^{\circ} 01^{\prime} \mathrm{S}, 52^{\circ} 06^{\prime} \mathrm{W}\right)$, Rio Grande (RS, Brazil). Pólvora Island is completely covered by 45 ha of undisturbed estuarine salt marsh (Costa 1997a). Low marshes are mostly colonized by Spartina alterniflora, while mid marshes are dominated by either Spartina densiflora or Scirpus maritimus, and a shrub zone, dominated by Myrsine parvifolia A.D.C., and the halophytic fern Acrosticum danaefolium Langsd. \& Fish occur on the high marsh. Monospecific stands of S. maritimus and $S$. densiflora are also found colonizing mud flats of the low marsh. The climate is hot-temperate, with clear seasonal fluctuations; lowest $\left(13^{\circ} \mathrm{C}\right)$ and highest $\left(25^{\circ} \mathrm{C}\right)$ average air temperatures are observed in July and January, respectively. Marsh dominants show specific seasonal growth cycles. $S$. maritimus behaves as a cryptophyte with aerial parts sprouting from its rhizomes at the end of winter, peak growth at the end of spring and tillers completely dying back in mid-autumn (Seeliger et al. 1997; Costa 1998). Both Spartina species are C4 phanerophytes with slow winter-spring growth and growth peaks in the summer and autumn (Silva et al. 1993; Copertino et al. 1997; Seeliger et al. 1997).

\section{ABIOTIC DATA}

The variability of water level in the Patos Lagoon estuary was assessed by comparing flooding frequencies in the intertidal zone between years (each annual period lasts from July until the following June). Water level
Ecological Society, Journal of Ecology, 91, 951-965 
Irregularly flooded marsh

(C) 2003 British Ecological Society, Journal of Ecology, 91, 951-965 and salinity have been monitored daily since July 1992 at the southern part of Marinheiro Island (1 km north of the study area). Water level was determined to the nearest $\mathrm{cm}$, between 10.00 and $11.00 \mathrm{~h}$ at a fixed station, and related to the mean water level (MWL) of the estuary between July 1992 and June 2001.

To document variation in physical stress within vegetation zones at Pólvora Island, pore water salinity, $\mathrm{pH}$ and redox potential of the surface sediment $(10 \mathrm{~cm})$ were measured at 10 sampling points along a $410-\mathrm{m}$ transect. The pore water samples were obtained between April and August 1995 ( $n=10$ dates) with a hand vacuum pump (model 2005G2, Soilmoisture Equip. Corp., Santa Barbara, CA, USA), by inserting the bottomless collection cylinder $10 \mathrm{~cm}$ into the sediment. The sampling points corresponded to zones dominanted by Spartina alterniflora (points 1 and 2), S. densiflora (3, 4, 5 and 9), Scirpus maritimus (6, 7 and 8) and high marsh shrubs (Myrsine parvifolia; point 10), respectively. In January 2000, three cores (top $10 \mathrm{~cm}$ ) were randomly collected in the low and mid marsh vegetation zones. The sediment was air-dried and passed through a 2-mm sieve before laboratory analysis. The total organic content was estimated by combustion at $500{ }^{\circ} \mathrm{C}$ for $6 \mathrm{~h}$ (Brower \& Zar 1977). Total Kjedahl nitrogen concentration in the sediment was determined and the concentration of exchangeable phosphate estimated by colourimetry (Allen et al. 1976).

\section{RECIPROCAL TRANSPLANTS}

Transplants were established in June 1995. Three adjacent monospecific stands of Spartina alterniflora, $S$. densiflora and Scirpus maritimus (hereafter called 'zones'), each covering c. $2500 \mathrm{~m}^{2}$, were chosen for the experiment. The elevation of each zone was estimated with a level and express relative to the water-level monitoring site, to allow us to estimate their flooding frequencies (percentage of days). Thirty blocks of sediment of $20 \times$ $20 \times 20 \mathrm{~cm}$, including tillers, rhizomes and roots of each species (hereafter called 'turfs'), were excavated from each of the monospecific zones. Ten were transplanted to similar-sized holes in each of the true zones (i.e. manipulation controls). Ten blocks were placed in the other species zones. In each zone, half of the transplants $(n=5)$ of each species were placed in direct contact with the surrounding vegetation and the other half $(n=5)$ had all neighbouring plants in a $25-\mathrm{cm}$ wide strip around the perimeter removed by clipping their shoots at ground level. All biological measurements were made within the $0.031-\mathrm{m}^{2}$ central areas of the turfs delimited by a PVC ring with $20 \mathrm{~cm}$ diameter, fixed to the sediment with metal pins. To avoid invasion by roots of surrounding plants, all neighbour-removal areas were cut to a depth of $25 \mathrm{~cm}$ with a spade, $25 \mathrm{~cm}$ outside their perimeter. The clipping and severing were maintained for several weeks until neighbours ceased to grow back into the neighbour-removal area. This methodology allowed us to account for the overall competitive effect of neighbouring vegetation and the impact of local physical stresses on target transplanted plants (Bertness 1991a, 1991b; Pennings \& Callaway 1992; Emery et al. 2001; Pennings \& Moore 2001; Pennings et al. 2003).

Five times during the period of study (31 August 1995, 26 October 1995, 24 November 1995, 30 January 1996 and 27 February 1996, hereafter referred to as 'late winter 1995', 'early spring 1995', 'late spring 1995', 'early summer 1996' and 'mid-summer 1996', respectively), the number of live tillers, reproductive tillers (with flowers/seeds) and tillers with crab wounds from Chasmagnathus granulata were determined in each turf. A tiller was considered grazed when it had small scratches or part or all of the tiller had been removed. The small Grapsid crab Metasesarma rubripes Rathbun (1897) (Capitoli et al. 1977) was also observed in the local marsh but it feeds mainly on plant detritus. Insect herbivory was negligible and appeared uniform for all three plant species.

The final harvest of all tillers inside PVC rings was done by clipping at ground level at the growth peak of each species. Because of the early growing season of $S$. maritimus (Costa 1998) it was harvested in early summer 1996, whereas the two perennial grasses (S. alterniflora and $S$. densiflora) were collected in mid-summer 1996. In the laboratory the heights of all tillers were measured and, after removing dead plant material, dried at $80{ }^{\circ} \mathrm{C}$ for $48 \mathrm{~h}$ and weighed. Between-treatment differences in height were analysed using only the 10 tallest tillers per turf of $S$. densiflora and the five tallest tillers per turf of S. alterniflora and S. maritimus (where stands are less dense due to their architecture). Maximum tiller height was used as indicator of the growth potential of each species under the experimental conditions as it excludes bias in the average height due to betweenturf variation of tiller density and recently sprouted tillers. The percentage of flowering tillers was calculated including only tillers of height equal to or taller than the minimum height from which flowering was observed $(S$. densiflora $=10 \mathrm{~cm} ; S$. alterniflora $=45 \mathrm{~cm}$; $S$. maritimus $=45 \mathrm{~cm}$ ). Additionally, six plants of each species were collected from their natural zones and the Kjeldahl N concentration of the leaves was determined (Allen et al. 1976).

\section{DATA ANALYSES}

Because of the great temporal variability in pore water salinity, $\mathrm{pH}$ and redox, the assumptions of homogeneity of variances and normality were not met with the usual transformations. The Kruskal-Wallis test was used to test for differences between sampling points and between vegetation zones (i.e. sampling points grouped by local plant cover) at the 5\% significance level (Siegel 1975). When significant differences were found for the KruskalWallis test, pairwise comparisons by Mann-Whitney $U$-test were made at the $1 \%$ significance level (Siegel 1975).

Although transplanted plants were measured five times, statistical analyses are presented only for the 
C. S. B. Costa, J. C. Marangoni \& A. M. G. Azevedo final harvest. To test whether grazing intensity by crabs affected transplanted plant performance, the percentage of tillers per turf with wound marks induced by Chasmagnathus was correlated with density and average maximum height of tillers, percentage of flowering tillers and live aerial biomass of the three species using the non-parametric Spearman correlation (Siegel 1975).

One-way ANOvAs (Zar 1984) were performed to test for differences in the concentrations of sediment organic matter, total nitrogen and exchangeable phosphate between vegetation zones and of leaf nitrogen content between species. Transplant performance was analysed using two-way ANOVA within each transplant species, with vegetation zone ('Z'; $S$. densiflora, $S$. alterniflora and $S$. maritimus) and the presence of competitors (' $C$ '; with and without competition) as fixed effects and including their interaction term (Z X C). For S. alterniflora biomass and density analyses, turfs that were completely eaten during the experiment were included, but given values equal to 0 . Analyses of the averages of maximum tiller height and percentage of flowering tiller included only the surviving turfs and their ANOVAs were therefore not balanced. Sediment organic matter, total nitrogen and exchangeable phosphate data were squareroot transformed, leaf nitrogen content data were $\log _{10}(x)$ transformed, tiller density data were square-root $(x+1)$ transformed, biomass data were $\log _{10}(x+1)$ transformed and percentage of flowering tiller data were arcsin square-root transformed to increase homogeneity of variance and normality and all ANOVAs were performed at the 5\% significance level. When a main effect or interaction factor was significant, mean comparisons were performed by Tukey multiple comparison tests at the 5\% significance level (Zar 1984).

The relative competition intensity (RCI) was estimated by the relative reduction in the average turf performance due to neighbours, i.e. the difference in a plant attribute without and with neighbours, divided by that attribute without neighbours. Although RCI is most widely used for biomass (Rozema et al. 1988; Keddy 1989; Grace 1995; Williams \& McCarthy 2001), we also applied for tiller density and maximum height to evaluate how competition affects these different aerial components. If $\mathrm{RCI}=0$, there is no effect of a competitor, whereas if it is positive, the target species has poorer performance in the presence of neighbours and competition is therefore indicated. If the RCI is negative, the target species is benefiting from facilitation.

\section{Results}

PHYSICAL STRESS AND EDAPHIC CONDITIONS

Hydrological data are shown for low-water (autumn) and high-water (winter) periods as well as overall (Fig. 1, Table 1). The Pólvora Island salt marsh extended over only $36 \mathrm{~cm}$ in elevation between a $S$. alterniflora low marsh (points 1 and 2; -1 to $+8 \mathrm{~cm} \mathrm{MWL)} \mathrm{and} \mathrm{dense}$
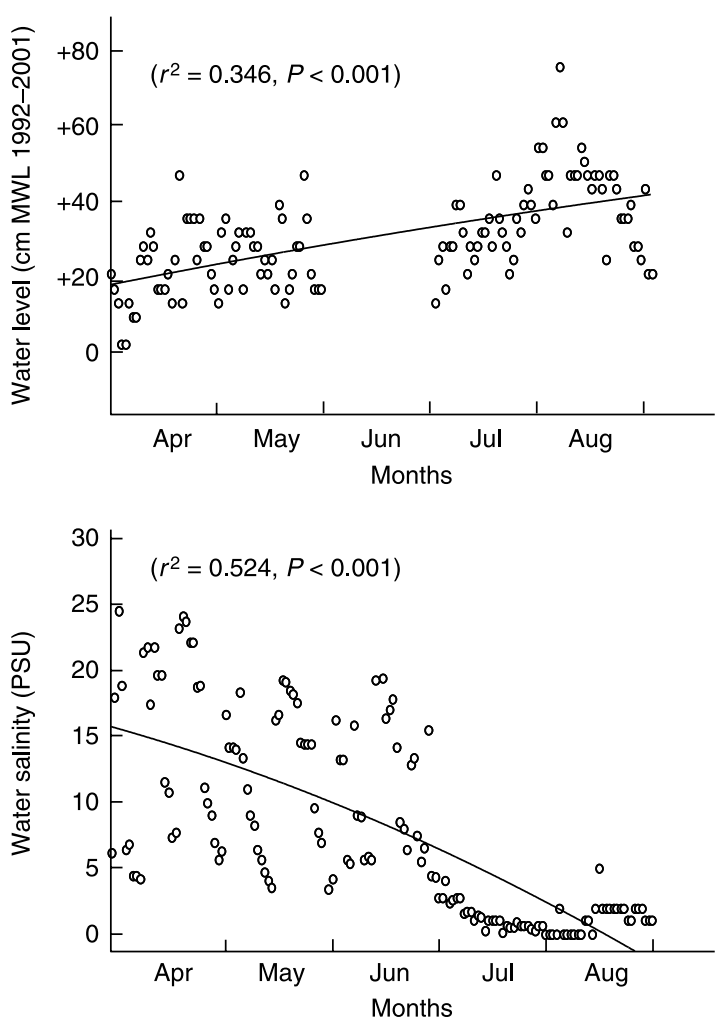

Fig. 1 Daily variation in water level and salinity of the Patos Lagoon estuary between April and August 1995. Linear and polynomial curves were fitted to highlight seasonal trends.

shrub cover on the top of the sand bank that bounded the island (Fig. 2).

The highest values of salinity and $\mathrm{pH}$ were observed during the autumn (Table 1). There were no statistical differences in salinity, $\mathrm{pH}$ or redox potential of the pore water between zones with different dominant species for either the overall period of monitoring or the lowwater and high-water periods (Table 1). Redox potential (overall and autumn analyses) and $\mathrm{pH}$ (autumn) were, however, significantly different between sampling points. A $S$. densiflora stand just above the drift-line zone (point 3; +14 cm MWL) had more reducing sediment than a mid marsh stand of the same species at higher elevation (point 9; +25 cm MWL) (Fig. 2, Table 1). For the autumn period, significantly lower $\mathrm{pH}$ values were found in organic-rich sediments of $S$. densiflora or shrubs on higher ground (points 9 and 10) and higher values in marginal $S$. alterniflora-S. densiflora marshes frequently washed by alkaline waters (points $1-3$ ).

The analysis of flooding frequency pattern across the intertidal zone showed great variability between years (Fig. 3). Maximum interannual amplitudes of variation occurred in the low marsh and lower mid marsh zones $(-15$ to $+15 \mathrm{~cm} \mathrm{MWL})$, where they ranged from $38 \%$ to $56 \%$ (Fig. 3b). Thus at MWL, a height colonized by all three species, plants can be flooded for as little as $24 \%$ or as much as $80 \%$ of the time, depending on the year considered (Fig. 3a).

Daily changes in water level can frequently be as large as $10-20 \mathrm{~cm}$ (Figs 1 and 4a), sufficient to expose
Journal of Ecolo 91, 951-965 
955

Irregularly flooded marsh
(C) 2003 British Ecological Society, Journal of Ecology, 91, 951-965
Table 1 Mean values $( \pm$ SE) of pore water salinity, $\mathrm{pH}$ and redox potential of 10 sampling points located across the Pólvora Island salt marsh (see Fig. 2). Kruskal-Wallis test was applied to compare sampling points and vegetation zones (sampling points grouped according to their plant cover)

Kruskal-Wallis test

\begin{tabular}{|c|c|c|c|c|c|}
\hline \multirow[b]{2}{*}{ Analysis } & \multirow[b]{2}{*}{ Variables } & \multirow[b]{2}{*}{$n$} & \multirow[b]{2}{*}{ Average } & \\
\hline & & & & Sampling point & Vegetation zone \\
\hline \multirow[t]{3}{*}{ Overall } & Salinity (PSU) & 100 & $\begin{array}{l}12.9 \pm 0.8 \\
(0-26)\end{array}$ & $4.7 \mathrm{NS}$ & $0.6 \mathrm{NS}$ \\
\hline & $\mathrm{pH}$ & 100 & $\begin{array}{l}6.7 \pm 0.1 \\
(5.4-8.5)\end{array}$ & $15.9 \mathrm{NS}$ & $7.0 \mathrm{NS}$ \\
\hline & Redox (mV) & 100 & $\begin{array}{l}+175 \pm 11 \\
(-115-+371)\end{array}$ & $17.7^{*}$ & $2.2 \mathrm{NS}$ \\
\hline \multirow[t]{3}{*}{$\begin{array}{l}\text { Autumn } \\
1995\end{array}$} & Salinity (PSU) & 50 & $\begin{array}{l}17.3 \pm 0.7 \\
(7-26)\end{array}$ & $7.2 \mathrm{NS}$ & $1.9 \mathrm{NS}$ \\
\hline & $\mathrm{pH}$ & 50 & $\begin{array}{l}6.2 \pm 0.1 \\
(5.4-7.4)\end{array}$ & $20.8^{*}$ & $5.3 \mathrm{NS}$ \\
\hline & Redox (mV) & 50 & $\begin{array}{l}+215 \pm 10 \\
(+46-+371)\end{array}$ & $19.5^{*}$ & $4.6 \mathrm{NS}$ \\
\hline \multirow[t]{3}{*}{$\begin{array}{l}\text { Winter } \\
1995\end{array}$} & Salinity (PSU) & 50 & $\begin{array}{l}8.1 \pm 1.2 \\
(0-21)\end{array}$ & $1.5 \mathrm{NS}$ & $0.5 \mathrm{NS}$ \\
\hline & $\mathrm{pH}$ & 50 & $\begin{array}{l}7.1 \pm 0.1 \\
(6.1-8.5)\end{array}$ & $16.5 \mathrm{NS}$ & $6.6 \mathrm{NS}$ \\
\hline & Redox (mV) & 50 & $\begin{array}{l}+114 \pm 16 \\
(-115-+300)\end{array}$ & $12.3 \mathrm{NS}$ & $2.4 \mathrm{NS}$ \\
\hline
\end{tabular}

$\mathrm{NS}=$ not significant; ${ }^{*} P<0.05$.

Table 2 Results of two-way ANOva for crab grazing intensity and attributes of transplanted plants (data aggregated per species) for the factorial effects of zone location (z) and competition (c; presence/absence of neighbours). $F$-values of ANOvA not including the heavily grazed $S$. maritimus zone are shown (inside boxes) only when this procedure produced changes in the significance of the tested factors or bifactorial interaction. Analysed species: $S d=S$. densiflora, $S a=S$. alterniflora, $S m=S$. maritimus

\begin{tabular}{|c|c|c|c|c|c|c|c|c|c|}
\hline & \multicolumn{3}{|l|}{$S d$} & \multicolumn{3}{|l|}{$S a$} & \multicolumn{3}{|l|}{$S m$} \\
\hline & $\mathrm{Fz}$ & $\mathrm{Fc}$ & $\mathrm{Fz} \times \mathrm{c}$ & $\mathrm{Fz}$ & $\mathrm{Fc}$ & $\mathrm{Fz} \times \mathrm{c}$ & $\mathrm{Fz}$ & $\mathrm{Fc}$ & $\mathrm{Fz} \times \mathrm{c}$ \\
\hline Grazed tillers (\%) & $28.92 * * *$ & 0.28 & 0.03 & $60.19 * * *$ & 1.12 & 2.32 & 1.47 & 0.10 & 0.10 \\
\hline \multirow[t]{2}{*}{ Tiller density } & 0.52 & $8.31^{*}$ & 0.09 & $51.95^{* * *}$ & $10.16^{*}$ & $6.33^{*}$ & 0.66 & 2.93 & 0.88 \\
\hline & & & & $12.76^{*}$ & $25.51^{*}$ & 0.08 & & & \\
\hline \multirow[t]{2}{*}{ Maximum tiller height } & $54.03^{* * *}$ & $92.15 * * *$ & $4.18 *$ & $246.14^{* * *}$ & 0.73 & $26.88 * * *$ & 1.01 & $13.56^{* *}$ & 2.58 \\
\hline & & & & $37.46 * * *$ & $34.18 * * *$ & 0.18 & & & \\
\hline \multirow[t]{2}{*}{ Live biomass } & $7.67^{*}$ & $11.01 *$ & $3.76^{*}$ & $22.33 * * *$ & 1.71 & 3.22 & 2.75 & 3.35 & 1.86 \\
\hline & 0.01 & $19.72 * *$ & 0.01 & 0.89 & $10.48^{*}$ & 0.11 & & & \\
\hline Flowering tillers (\%) & $9.34 *$ & $4.79 *$ & 0.83 & 1.23 & 1.08 & 1.05 & $5.56^{*}$ & 2.02 & 0.22 \\
\hline
\end{tabular}

$P<0.05,{ }^{* *} P<0.01,{ }^{* * *} P<0.001$.

or flood most of the marsh. During the experiment, water level of the Patos Lagoon estuary varied (Fig. 4a) but on average was $+11 \pm 17 \mathrm{~cm} \mathrm{MWL}( \pm \mathrm{SD})$. Water salinity averaged $7 \pm 8$ PSU (slightly lower than the 10year average of $9 \pm 8$ PSU). Characteristic seasonal patterns of salinity and water level were also observed (Fig. 1). The monospecific zones of the reciprocal transplantation experiment dominated by $S$. densiflora, $S$. alterniflora and S. maritimus were flooded $28 \%, 37 \%$ and $43 \%$ of the time during the study period, respectively (Fig. 4a). The sediment of the S. densiflora zone had higher concentrations of organic matter $(8.4 \pm 0.5 \%)( \pm \mathrm{SE})$ and total nitrogen $\left(1.6 \pm 0.2 \mathrm{~g} \mathrm{~kg}^{-1}\right)$ than the $S$. maritimus zone (Fig. 4b), but nitrogen concentrations were not significantly different between zones $(F=4.4, P=0.07)$.
Higher concentrations of exchangeable phosphate were found in S. alterniflora $\left(52.8 \pm 0.7 \mathrm{mg} \mathrm{kg}^{-1}\right)$ and $S$. maritimus $\left(49.5 \pm 2.0 \mathrm{mg} \mathrm{kg}^{-1}\right)$ zones than in the $S$. densiflora zone $\left(37.7 \pm 3.9 \mathrm{mg} \mathrm{kg}^{-1}\right)$ (Tukey $\left.P<0.05\right)$ (Fig. 4b).

\section{CRAB HERBIVORY}

Chasmagnathus ate tillers of all three species during the study, although fewer tillers showed damage in spring 1995 (data not presented). At the end of the experiment significantly higher grazing intensities by Chasmagnathus were recorded for $S$. alterniflora $(\mathrm{Fz}=60.2, P<$ $0.001)$ and $S$. densiflora tillers $(\mathrm{Fz}=28.9, P<0.001)$ when they were transplanted to the $S$. maritimus zone rather than to other zones (Table 2, Fig. 5). Crab and crab 
956

C. S. B. Costa,

J. C. Marangoni \& A. M. G. Azevedo
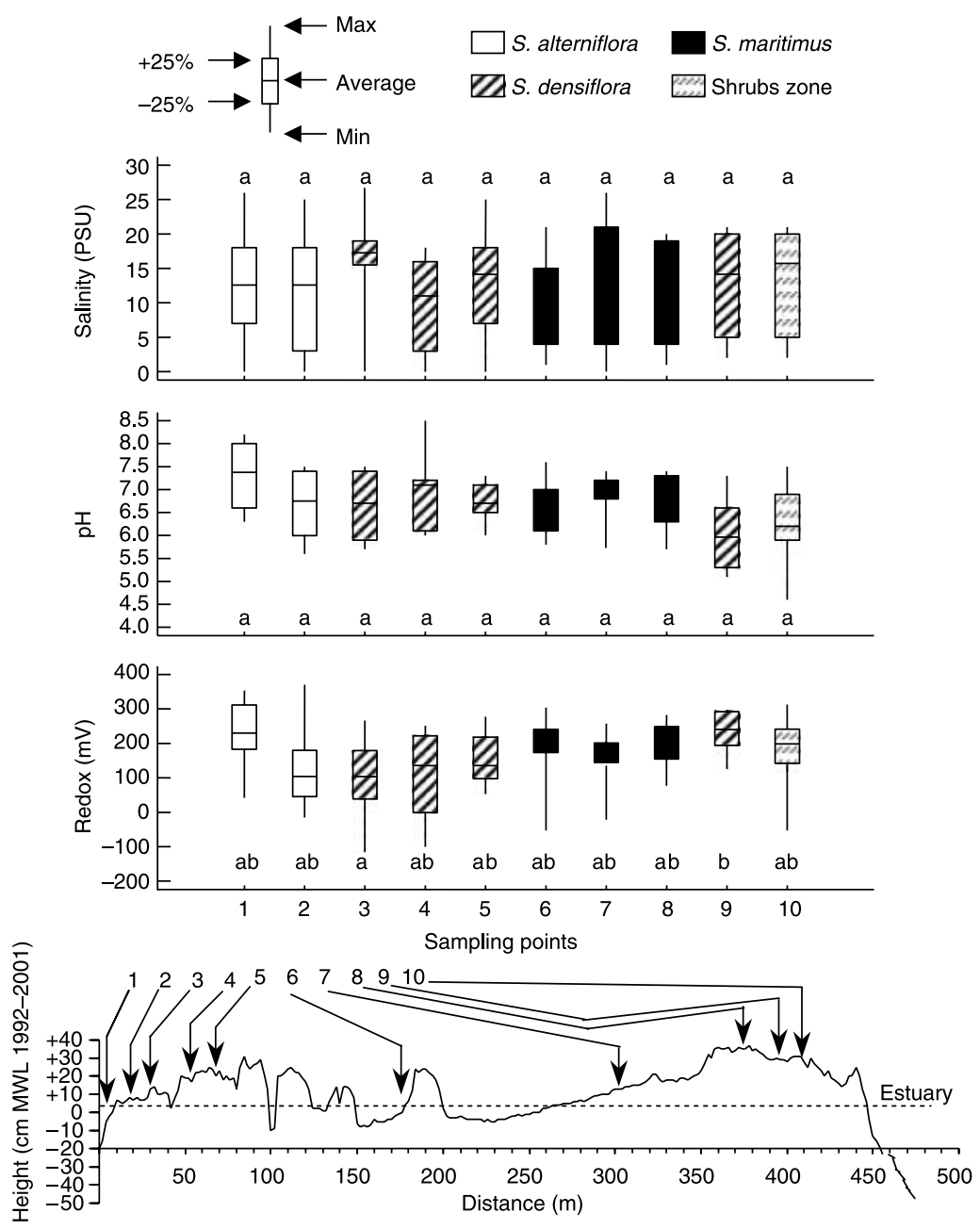

Fig. 2 Pore water salinity, pH and redox potential values between April and August 1995 at 10 sampling points located across Pólvora Island salt marsh ( $n=10$ sampling dates). Average, minimum and maximum observed values, as well as first data quarter above and below the average, are shown. Vegetation zones are represented by different pattern. Lower case letters indicate significant differences (Mann-Whitney $U$-test, $P<0.01$ ) between sampling points for each environmental characteristic for the overall monitoring period (see Table 1).

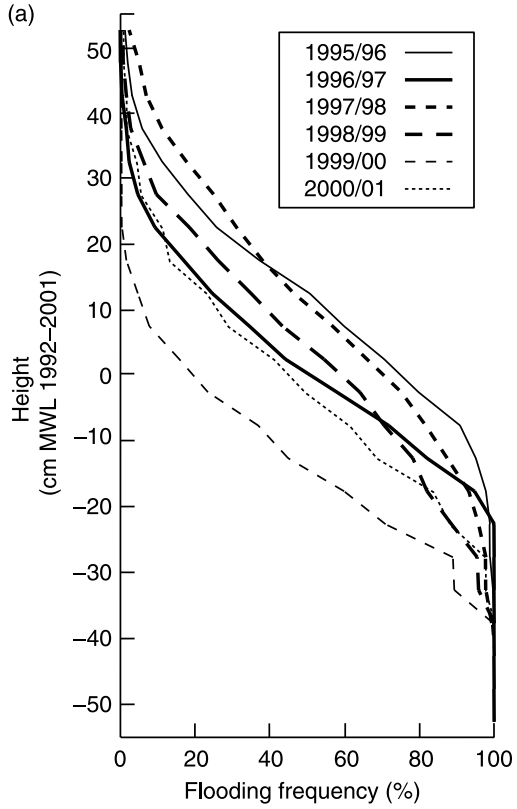

(b)

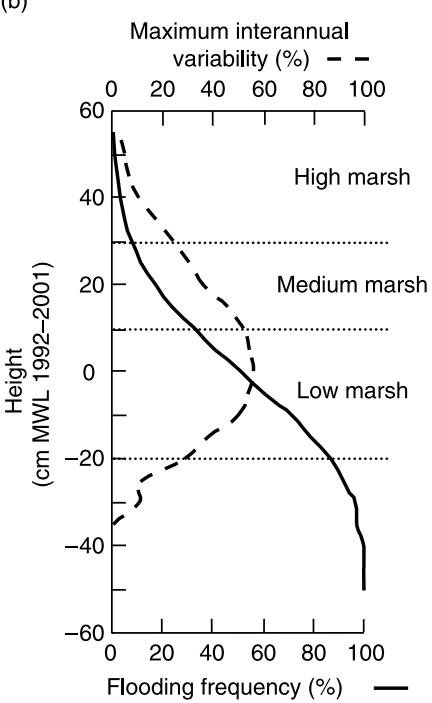

(C) 2003 British Ecological Society, Journal of Ecology, 91, 951-965
Fig. 3 (a) Annual flooding frequency curves for 1995-2001. (b) Ten-year (for 1992-2001) average flooding frequency and maximum amplitude of interannual variation in frequency observed at each tidal elevation. Graphs were calculated in 5-cm intervals from the water level measurements. Topographic marsh zones were defined according to Costa (1997a). 
957

Irregularly flooded marsh
(C) 2003 British Ecological Society, Journal of Ecology, 91, 951-965

(a)

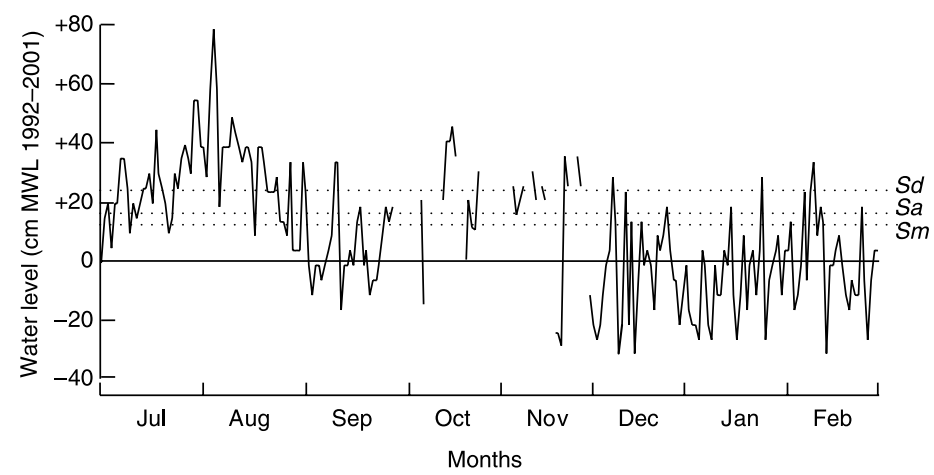

(b)

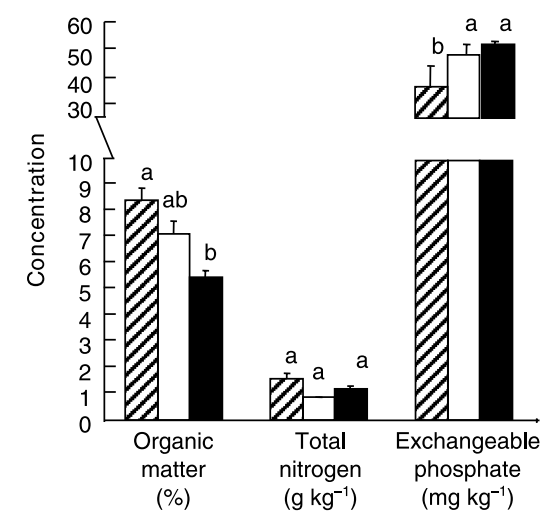

Fig. 4 Daily variation in water level of the Patos Lagoon estuary between July 1995 and February 1996 (a) and average concentrations $( \pm \mathrm{SE})$ of organic matter, total nitrogen and exchangeable phosphate in the surface sediment (b) of the zones dominated by $S$. densiflora ( $S d$; stripes), $S$. alterniflora ( $\mathrm{Sa}$; white) and $S$. maritimus ( $\mathrm{Sm}$; black). Height of each vegetation zone (dashed horizontal lines). Some water level data are missing for October and November 1995. Lower case letters indicate significant differences (posteriori Tukey test $P<0.05$ ) between zones within each sediment parameter.

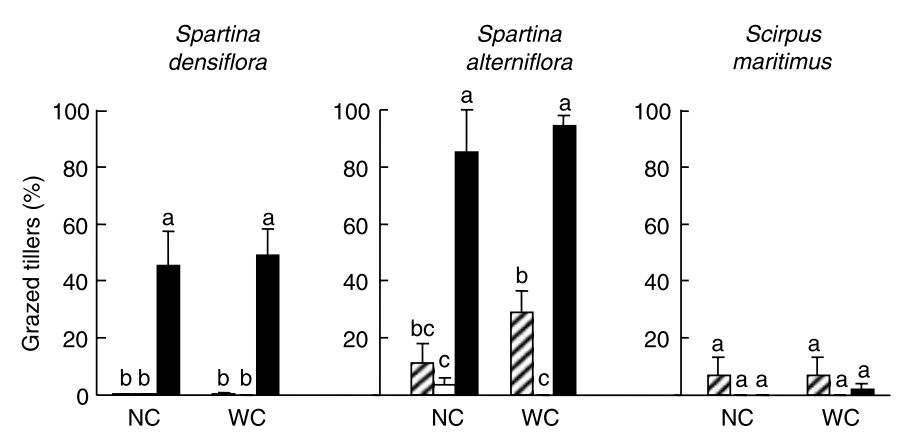

Fig. 5 Mean percentage $( \pm \mathrm{SE})$ of tillers grazed by Chasmagnathus granulata crabs when transplanted into zones dominated by S. densiflora (stripes), S. alterniflora (white) and S. maritimus (black). Lower case letters indicate significant differences (posteriori Tukey test $P<0.05$ ) between zones and competition treatments $(\mathrm{NC}=$ no competition, $\mathrm{WC}=$ with competition $)$ within each species.

burrow densities appeared to be uniform for all zones. In the S. maritimus zone, regardless of whether or not neighbours were present, S. alterniflora tillers were more frequently grazed (average of turfs without competition $=85.2 \%$ of tillers, with competition $=94.4 \%$ of tillers) than $S$. densiflora tillers (without competition $=45.5 \%$ and with competition $=48.9 \%)($ Fig. 5). The lowest percentage of $S$. alterniflora-grazed tillers occurred in its own zone $(P<0.05$, Turkey test). S. maritimus was rarely grazed, and grazing on $S$. maritimus did not differ between zones or neighbour removal treatment levels (Table 2, Fig. 5).
Chemical analyses showed that the leaf nitrogen content of $S$. densiflora $\left(5.4 \pm 0.3 \mathrm{mg} \mathrm{g}^{-1}\right)$ was significantly lower $(F=22.2, P<0.001)$ than for leaves of $S$. alterniflora $\left(9.7 \pm 0.5 \mathrm{mg} \mathrm{g}^{-1}\right)$ and $S$. maritimus $(12.1 \pm$ $\left.2.7 \mathrm{mg} \mathrm{g}^{-1}\right)$.

There was no significant correlation between grazing intensity and performance of S. maritimus. Increasing crab herbivory, however, significantly decreased the growth of both Spartina species (Fig. 6). Although $S$. densiflora maximum tiller height, live aerial biomass and percentage of flowering tillers were negatively correlated with grazing intensity by crabs, tiller density 
C. S. B. Costa,

J. C. Marangoni \& A. M. G. Azevedo
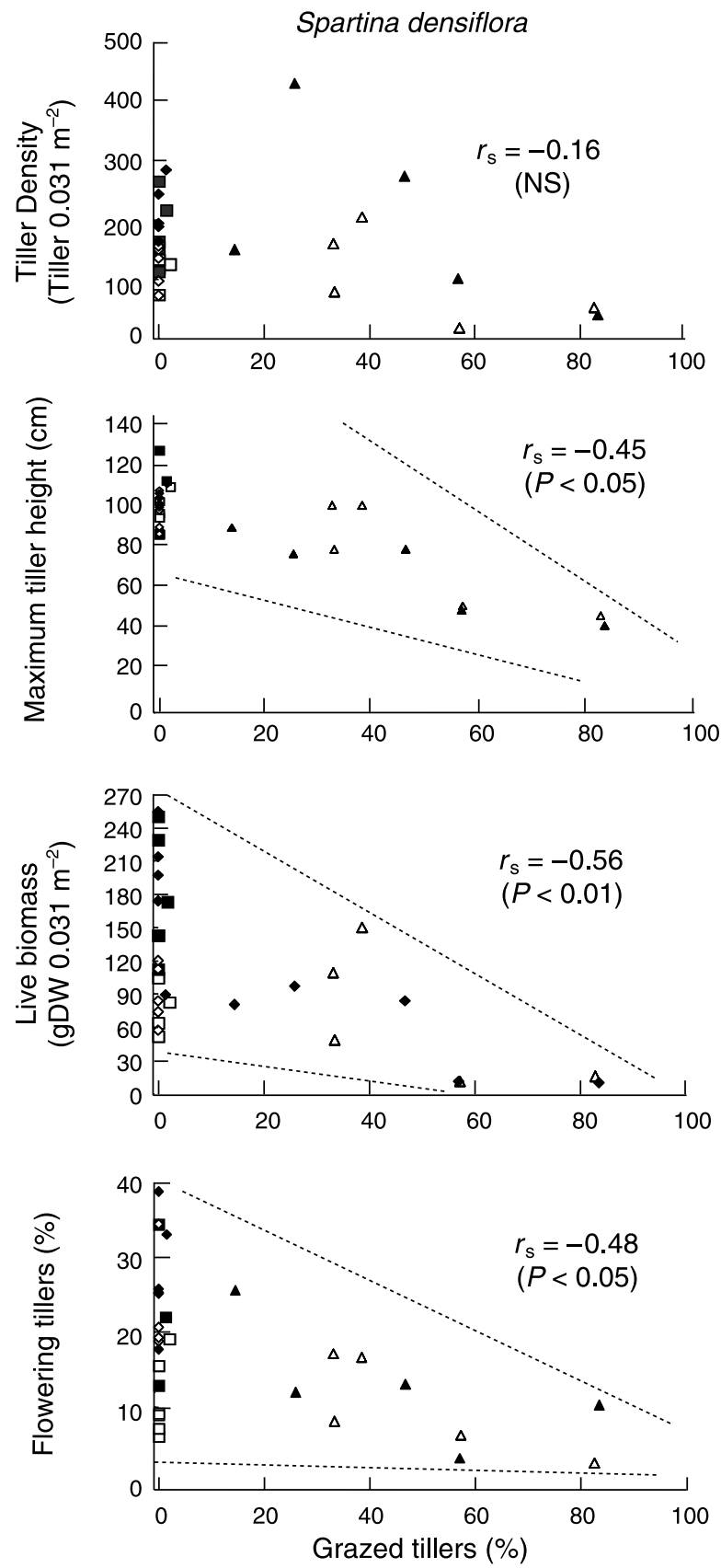

Spartina alterniflora
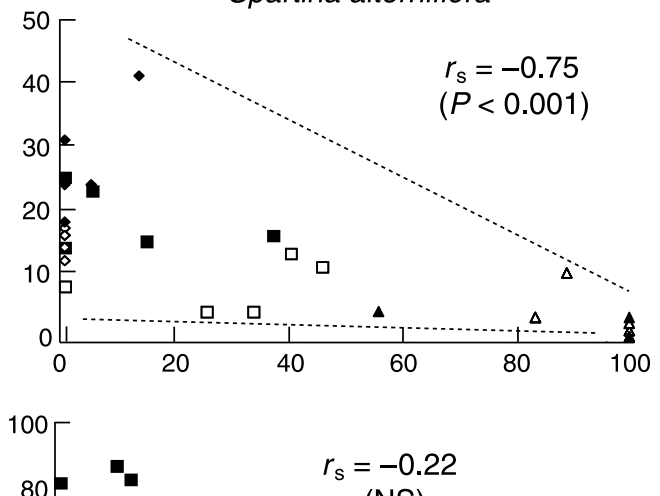

(NS)

口
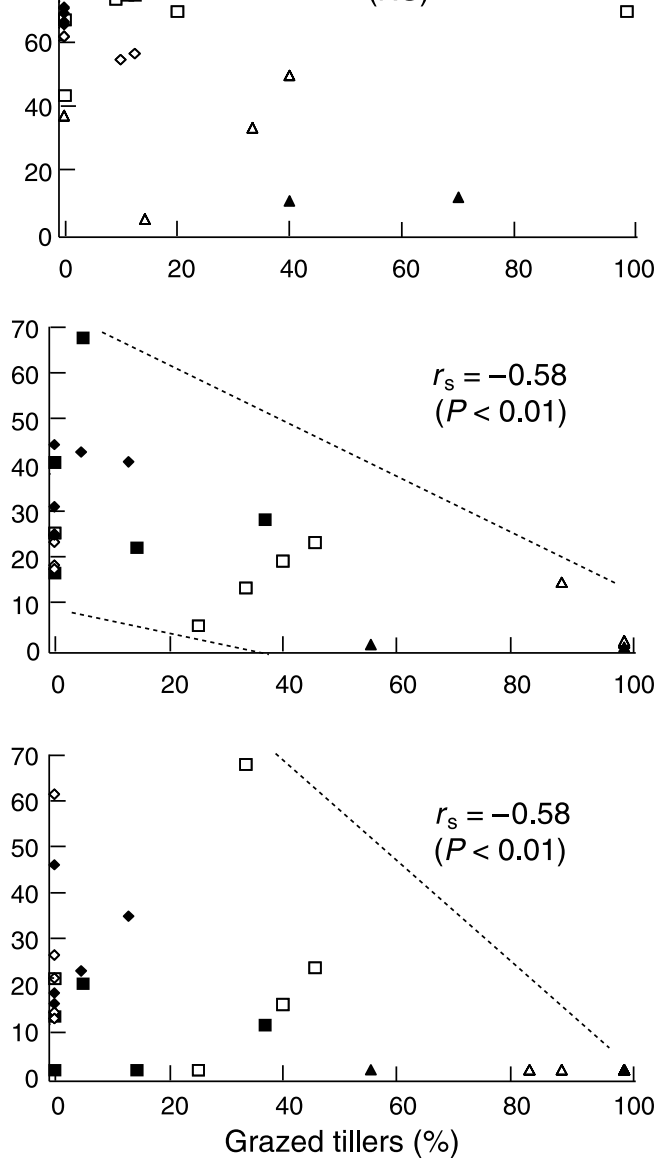

Fig. 6 Effects of grazing intensity by Chasmagnathus granulata crabs on the final performance of $S$. densiflora and S. alterniflora. Dotted lines show data scattering; open and filled symbols represent data from transplants with and without competition; squares represent the $S$. densiflora zone, diamonds the $S$. alterniflora zone and triangles the $S$. maritimus zone.

was not significantly affected (Fig. 6). In contrast, tiller density of $S$. alterniflora was greatly reduced by increasing intensity of crab grazing (Fig. 6). As the percentage of flowering tillers was also inhibited by grazing both the vegetative spread of rhizomes and the reproductive success of S. alterniflora may be strongly limited by Chasmagnathus food preference.

\section{VARIATION IN PLANT PERFORMANCE}

\section{WITHOUT COMPETITION}

Ecological Society, Journal of Ecology, 91, 951-965
$S$. maritimus was not influenced by zone (Fz ANOVA $P$ $>0.05$ for density, maximum height and aerial biomass) except for having the highest percentage of flowering tillers in its own zone (Fig. 7, Table 2).

The evaluation of physical stress effects (zone effect) on $S$. alterniflora and $S$. densiflora was seriously compromised by Chasmagnathus selective grazing in the $S$. maritimus zone. ANOVAs of the two Spartina species were therefore performed both with and without data from the S. maritimus zone (Table 2). On average in turfs without neighbours, taller tillers of both Spartina species were found inside the $S$. densiflora zone and higher densities were observed in the $S$. alterniflora zone (Fig. 7). Additionally, $S$. densiflora showed a significantly higher percentage of flowering tillers in the $S$. alterniflora zone (Table 2). 
959

Irregularly flooded marsh
(C) 2003 British Ecological Society, Journal of Ecology, 91, 951-965
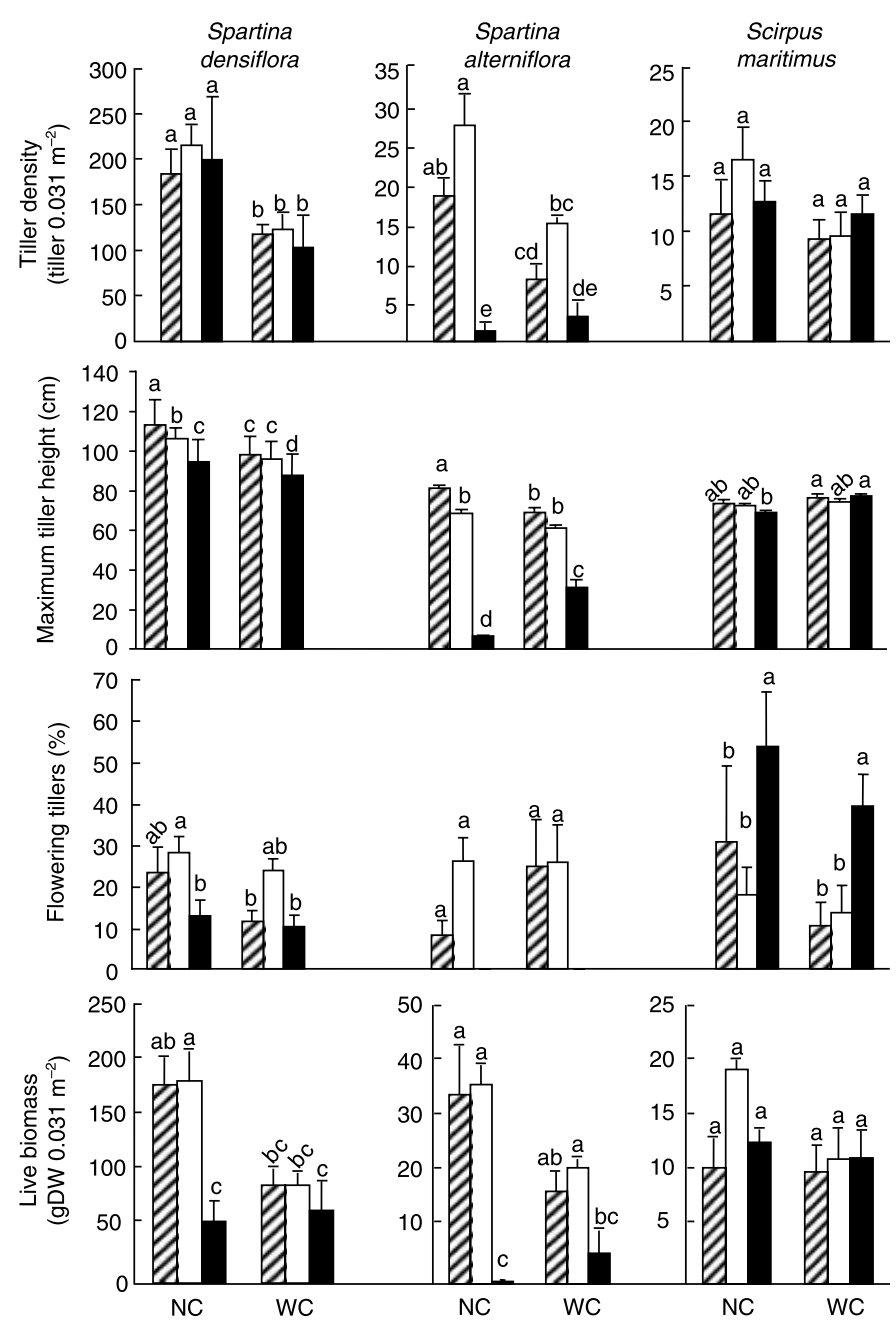

Fig. 7 Effects of competition $(\mathrm{NC}=$ no competition, $\mathrm{WC}=$ with competition $)$ and transplant location on mean $( \pm \mathrm{SE})$ tiller density, maximum height and flowering and live aerial biomass of the three dominant species. Lower case letters indicate significant differences (posteriori Tukey test $P<0.05)$ between zones $(S$. densiflora $=$ stripes; $S$. alterniflora $=$ white; $S$. maritimus $=$ black) and competition treatment within each species.

Significant differences in live biomass between zones were detected only when data from $S$. maritimus zone were included (Table 2). The lack of interzone differences in average live biomass of $S$. alterniflora and $S$. densiflora (Fig. 7) is consistent with their allocations to tillering or individual tiller height in each others' zones.

\section{COMPETITION AND POSITIVE EFFECTS}

S. densiflora and S. maritimus showed linear increases in average tiller densities in all treatments during the study but particularly for turfs without competition (Fig. 8). At the end of the experiment, regardless of vegetation zone, significantly lower tiller densities, maximum tiller heights, live aerial biomass and tiller flowering of $S$. densiflora were found in turfs growing with competition (Fc anovas $P<0.05$; Table 2). Significant interactions for $S$. densifora maximum tiller height and live aerial biomass (Table 2) also suggest variation in the intensity of neighbour effects between zones. However, the significance of these interaction terms and of the differences between zones (significant
$\mathrm{Fz}$ ) disappears when data from the $S$. maritimus zone are excluded from the analysis, indicating that differences in plant performance between zones were related to crab grazing effects. S. maritimus attributes measured in summer 1996 were not significantly affected by neighbour presence (Table 2, Fig. 7), except that the tallest tillers were found in turfs surrounded by neighbours $(\mathrm{Fc}=13.5, P<0.001)$. In this specific case, the only significant pairwise comparison between treatments (Tukey test $P<0.05$ ) was observed between turfs with $(76.7 \pm 1.1 \mathrm{~cm})$ and without neighbours $(68.5 \pm 1.0 \mathrm{~cm})$ inside $S$. maritimus own zone (Fig. 7).

$S$. alterniflora showed an increase in tiller densities in Spartina species zones, but starting in late spring 1995 (Fig. 8), whereas its average density in the $S$. maritimus zone fell throughout the experimental period. By late summer $1996 S$. alterniflora had high tiller densities in turfs without competition $(\mathrm{Fc}=10.2, P<0.05)$, provided they were in less grazed areas, both inside its conspecific zone $\left(28 \pm 2.2\right.$ tillers $\left.0.031 \mathrm{~m}^{-2}\right)$ and in the S. densiflora zone $\left(19 \pm 3.9\right.$ tillers $\left.0.031 \mathrm{~m}^{-2}\right)$ (Fig. 7). No other significant main effects of the competition 
960

C. S. B. Costa,

J. C. Marangoni \&

A. M. G. Azevedo

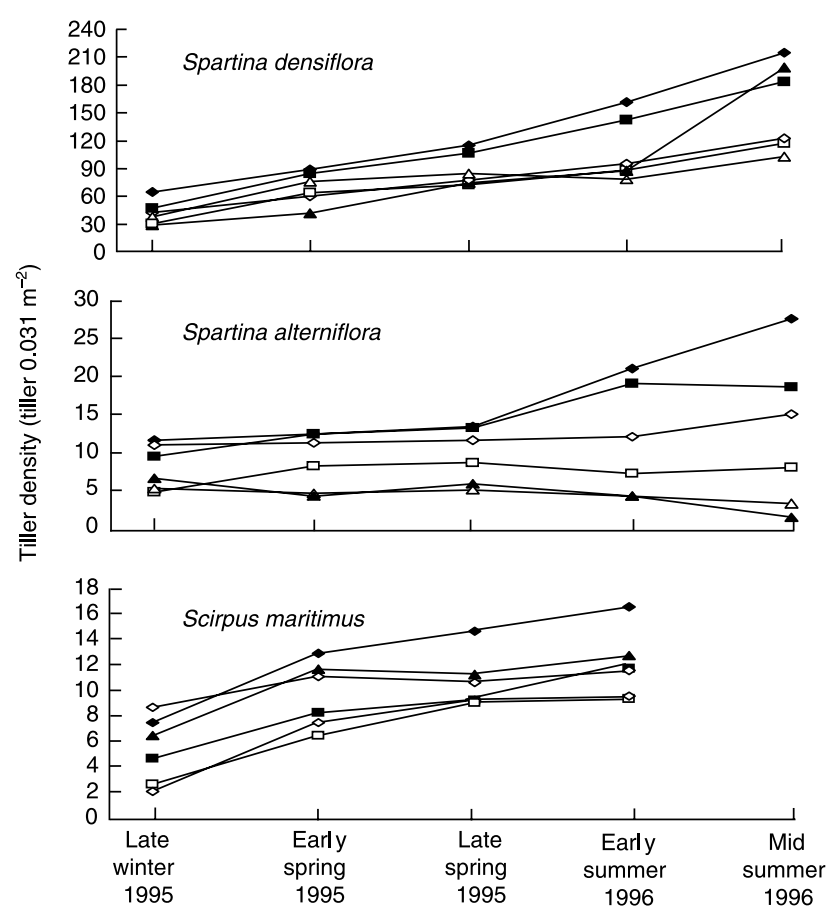

Fig. 8 Fluctuation of mean tiller density of the transplanted species in different zones ( $S$. densiflora $=$ stripes; S. alterniflora $=$ white; $S$. maritimus = black) and competition treatments (open and filled symbols represent data from transplants with and without neighbours, squares represent the $S$. densiflora zone, diamonds the $S$. alterniflora zone and triangles the $S$. maritimus zone).

Table 3 Relative competition intensity index (RCI) for different biological attributes of $S$. densiflora $(S d)$, S. alterniflora $(S a)$ and S. maritimus $(\mathrm{Sm})$ plants transplanted to three vegetation zones. Negative values indicate positive interactions

\begin{tabular}{|c|c|c|c|c|c|c|c|c|c|}
\hline \multirow[b]{2}{*}{ Transplanted zone } & \multicolumn{3}{|c|}{ Tiller density } & \multicolumn{3}{|c|}{ Maximum tiller height } & \multicolumn{3}{|c|}{ Live biomass } \\
\hline & $S d$ & $S a$ & $S m$ & $S d$ & $S a$ & $S m$ & $S d$ & $S a$ & $S m$ \\
\hline$S d$ & 36 & 57 & 19 & 14 & 15 & -4 & 51 & 51 & 4 \\
\hline$S a$ & 43 & 46 & 42 & 10 & 11 & -3 & 52 & 41 & 42 \\
\hline$S m$ & 48 & -128 & 9 & 8 & -397 & -12 & -18 & -850 & 10 \\
\hline
\end{tabular}

treatment were observed for S. alterniflora in these analyses, but significant interactions (tiller density and maximum height) were detected (Table 2). Two-way factorial ANOVAs performed without the data from the $S$. maritimus zone suggest that $S$. alterniflora density, maximum tiller height and live biomass were significantly depressed by conspecifics and by $S$. densiflora neighbours (Table 2, Fig. 7). The lack of significant interactions in these later analyses also suggested symmetry between intraspecific and interspecific competitive effects.

All three species demonstrated a great sensitivity of tiller density and live biomass to the presence of neighbours. RCI values indicated competition reduced average values by between $36 \%$ and $57 \%$ in the two Spartina species (Table 3). However, the overall performance of S. alterniflora was greatly improved (e.g. RCI $=-850 \%$ for live biomass) and live biomass of $S$. densiflora slightly increased $(\mathrm{RCI}=-18 \%)$ by the presence of neighbours in crab-grazed stands of $S$. maritimus. Maximum tiller height of the two Spartina species was little affected by congeneric presence $(\mathrm{RCI}<15 \%)$ and S. maritimus plants were consistently slightly taller $(4-12 \%)$ when surrounded by other plants (negative RCI values). The presence of $S$. alterniflora neighbours inhibited (42\%) S. maritimus tillering and live biomass but the same parameters were little affected by conspecifics or $S$. densiflora plants (RCI $<19 \%$ reduction).

\section{Discussion}

S. alterniflora, S. densiflora and S. maritimus were able to grow across the entire elevation gradient of the irregularly flooded low and mid marshes of Pólvora Island. Although selective herbivory by crabs affected the performance of both Spartina species and restricted the interpretation of the study results, strong intra- and interspecific competition was observed in all monospecific zones of the marsh. As no competitive hierarchy was detected, zonation in irregularly flooded low and mid marshes of southern Brazil seems to not be explained by the displacement of competitive subordinates to physically stressful habitats.
Ecological Society, Journal of Ecology, 91, 951-965 


\section{1}

Irregularly flooded

marsh

(C) 2003 British

Ecological Society,

Journal of Ecology,

91, 951-965
HYDROLOGICAL PERTURBATION AND THE ABSENCE OF A PHYSICAL GRADIENT

The irregularity and the relatively high amplitude of variation in hydrological conditions appear to explain the lack of a persistent physical stress gradient across the low and mid marshes of Patos Lagoon estuary. Persistent differences in physical factors between vegetation zones have been demonstrated for tidal and non-tidal salt marshes but are always related to regular patterns of flooding tides or rising/falling ground water levels. Marked differences of pore water redox (Bertness \& Ellison 1987; Odum 1988; Bertness 1991a; Castellanos et al. 1994; Portnoy \& Giblin 1997; Paludan \& Morris 1999; Castillo et al. 2000; Pennings \& Moore 2001; Figueroa et al. 2003) and salinity (Pennings \& Callaway 1992; Pennings \& Bertness 1999; Rogel et al. 2000; Pennings \& Moore 2001) have been found across elevation gradients at a wide range of latitudes. Differences between vegetation zones in surface sediment $\mathrm{pH}$ are less common but indirect factors such as organic content accumulation in older marshes and salt deposition/leaching in depressions can produce differences of 1-4 pH units (Vince \& Snow 1984; Bertness \& Ellison 1987; Paludan \& Morris 1999; Rogel et al. 2000). Similar ranges of redox, salinity and $\mathrm{pH}$ values were found along Pólvora Island marsh, but because of the flat landscape and the large amplitude of daily (Costa et al. 1988) and seasonal (Garcia et al. 2001; Möller et al. 2001) fluctuations in the estuary water level, differences between vegetation zones were not persistent in time and it is unlikely that they impose distribution limits for the dominant perennials. Furthermore, the sediments at Pólvora Island are typically well oxidized, with low salinity and nearly neutral $\mathrm{pH}$. These are ideal growth conditions for facultative halophytes (Lessmann et al. 1997; Pennings \& Moore 2001; Pennings et al. 2003), suggesting that most dominant plants are not physically limited in this system.

Episodes of warming (El Niño) and cooling (La Niña) of surface waters in the eastern tropical Pacific are highly correlated with excessive rainfall and drought, respectively, over the south-western Atlantic (Zhou \& Lau 2001; Coelho et al. 2002). These events possess a strong temporal stochastic component (Burgers 1999) and are responsible for a great part of the interannual variability in both the salinity pattern (Garcia et al. 2001; Seeliger \& Costa 2002) and flooding frequency of intertidal zones of the Patos Lagoon estuary (Fig. 3). Large and small fresh water discharges into the Patos Lagoon estuary are associated with periods of strong El Nino (1997/1998 data; Garcia et al. 2001) and La Nina (1999/2000 data; NOAA 2000, 2001) events in the Pacific Ocean. Interannual differences in estuarine water level can cause the physical stress gradient to move up and down the marsh elevation, particularly in low and mid marsh zones. Such conditions are not considered by the most common models explaining salt marsh structuring (Bertness 1991a, 1991b; Pennings \& Callaway 1992; Emery et al. 2001; Pennings \& Bertness 2001). These are based on the existence of a persistent physical stress gradient and therefore have limited use in the Patos Lagoon.

\section{CRAB HERBIVORY}

By the end of the growing season, on average, Chasmagnathus granulata grazing had reduced $S$. alterniflora biomass in the $S$. maritimus zone (averaged over competition treatments) by $366 \%$ in relation to its own zone. $S$. densiflora biomass was, however, reduced by only $10 \%$, although a strong preference for recently sprouted leaves when grazing on S. densiflora (Bortolus \& Iribarne 1999) means that grazing intensity of this species was probably underestimated. Selective herbivory by Chasmagnathus is similar to that of other Grapsidae crabs from mangroves (Robertson 1991; Lee 1998), and is probably related to anatomical and chemical differences between plant species (Lightfoot \& Whitford 1987; Robertson 1991; Lee 1998; Pennings et al. 1998). Lower sensitivity of $S$. densiflora to grazing seems to be explained by its clumped growth form and a capacity for rapid tillering in response to perturbation of its aerial parts (e.g. clipping, Silva et al. 1993, or burning, Bortolus \& Iribarne 1999); it also has lower palatability (it has more silica bodies in the epidermis and sclerenchyma fibres in its leaves than S. alterniflora; Santos \& Almeida 2000). S. alterniflora also has nitrogen leaf contents double those of $S$. densiflora, and $S$. maritimus has similar levels to $S$. alterniflora but none is present as easily assimilated compounds such as glycinebethaine and proline (up to $11 \%$ in Spartina sp.; Stewart et al. 1979; Parsons \& de la Cruz 1980; Cavalieri 1983).

Several herbivores (grazers, leaf suckers, seed eaters, etc.) utilize Spartina species in salt marshes around the world (Adam 1993; Furbish \& Albano 1994; Daehler \& Strong 1995; Bertness 1999; Davy et al. 2000). Herbivory by crabs (Robertson 1991; Wolcott \& O'Connor 1992; Lee 1998) and other organisms (Louda et al. 1990; Taylor et al. 1997; Silliman \& Zieman 2001; Silliman \& Bertness 2002) frequently limits the growth of grazed plants, and reduces biomass and/or tiller heights. Differential consumption of mangrove propagules by Grapsidae crabs can affect forest composition and may determine the local dominance of some trees (Robertson 1991; Lee 1998). Recent findings of strong top-down control of S. alterniflora by the gastropod Littoraria irrorata on the south-east coast of America (Silliman \& Zieman 2001; Silliman \& Bertness 2002) indicate that herbivores may also play a larger role in marsh plant community structure than is generally recognized (Pennings \& Bertness 2001). Our results suggest that Chasmagnathus herbivory can be very plant-selective, but evaluating crab effects on South American salt marshes will require further field experimentation.

\section{PHYSIOLOGICAL LIMITATION}

Few differences in the growth of transplanted plants could be exclusively related to physiological limitations 
962

C. S. B. Costa, J. C. Marangoni \& A. M. G. Azevedo imposed by variations in flooding frequency between zones. Scirpus maritimus grew similarly in all zones and the aerial biomass of $S$. alterniflora and $S$. densiflora plants without neighbours was practically identical in the two Spartina zones. For all three species flowering was stimulated in low zones, possibly due to higher concentrations of exchangeable phosphate (Salisbury \& Ross 1992) or low N : P ratios (van Wijnen \& Bakker 1999) in these areas. Both S. alterniflora and S. densiflora may benefit from lower flooding stress (Bertness 1991a; Castillo et al. 2000; Emery et al. 2001) or higher nitrogen availability (Mendelssohn 1979; Levine et al. 1998; Emery et al. 2001) of mid marshes. However, the results suggest that none of the three species experienced physiological growth restriction in any vegetation zone of the low and mid marshes.

\section{POSITIVE AND NEGATIVE PLANT INTERACTIONS}

The few instances where positive interactions (negative values of RCI) were recorded either occurred in the S. maritimus zone or were related to growth responses of $S$. maritimus. It is highly improbable that these effects were related to amelioration of salinity stress by neighbouring vegetation (Bertness \& Callaway 1994; Bertness 1999; Hacker \& Bertness 1999; Callaway \& Pennings 2000; Bortolus et al. 2002) because of the prevailing mesooligohaline conditions (Costa et al. 1988; Costa 1997b, 1998; Seeliger \& Costa 2002). As S. alterniflora plants growing beside $S$. maritimus are much more vulnerable to crab grazing than plants in Spartina stands, negative values of RCI of this species in the $S$. maritimus zone cannot be related to the association offering defence against herbivory (Bertness \& Ellison 1987; Davy et al. 2000; Pennings \& Bertness 2001). S. maritimus tillers have well-developed aerenchyma (Kantrud 1996) and oxidized iron is common near their roots (C. S. B. Costa, personal observation). Small patches of $S$. alterniflora cannot efficiently oxidize sediments of low marshes (Bertness 1991a) and amelioration of low oxygen levels by other species can generate positive interaction between marsh plants at low marsh elevations (Castellanos et al. 1994; Pennings \& Bertness 2001; Figueroa et al. 2003).

Most of the interactions were competitive, with $S$. alterniflora and $S$. densiflora demonstrating reduction in tiller density and maximum height, live aerial biomass and proportion of flowering tillers (in the case of $S$. densiflora) when surrounded by other plants. The lack of significant negative effects on $S$. maritimus could in part be an experimental artefact related to the short duration of the experiment ( 6 months) and the distinctive phenological cycles of $S$. maritimus and Spartina species in southern Brazil. On average, about $41-52 \%$ of the reduction in live aerial biomass of Spartina species can be accounted for by intra or interspecific competition. The negative interspecific responses (competition) are consistent with observations of growth inhibition by the presence of other plants ( $S$. densiflora, Kittelson
\& Boyd 1997; S. alterniflora, Bertness \& Ellison 1987; Bertness 1991a; Emery et al. 2001; Pennings et al. 2003).

Consequently, at least for Spartina species, intraand interspecific effects, although strong and consistent, appear to be symmetrical, with no marked variation in competitive intensity between vegetation zones. The evaluation of statistical differences in the magnitude of intra- or interspecific competitive effects, which would be reflected in significant interactions between the effects of competition and zone, was biased by the zone-dependent crab grazing (within the S. maritimus zone). Plant size (maximum height and aerial biomass), which is severely reduced in both species of Spartina by Chasmagnathus grazing, is a very important component of competitive ability (Keddy 1989; Bertness 1999). A competitive hierarchy does not, however, appear to be a major process structuring plant community of these irregularly flooded salt marshes, where the dominant species show considerable physiological tolerance. It is parsimonious to suggest that selective processes should favour stress tolerators as the dominant species of the mid marsh (e.g. S. densiflora) and that competition should occur at all elevations. Indeed, the mid marsh dominant, $S$. densiflora, can grow vigorously on low marshes (Costa 1997a; Kittelson \& Boyd 1997), within its physiological constraints of submergence time and minimum redox potential, which are not very different from those of low marsh dominants such as Spartina foliosa (Kittelson \& Boyd 1997) and Spartina maritima (Castillo et al. 2000).

\section{ZONATION IN IRREGULARLY FLOODED MARSHES OF SOUTHERN BRAZIL}

S. maritimus (in less saline estuaries; Ranwell 1974; Podlejski 1982; Kantrud 1996; Costa 1998) and S. densiflora (Costa 1997a; Castillo et al. 2000; Bortolus et al. 2002) are species capable of acting as salt marsh pioneers and persisting in more mature communities. These two species are certainly generalists and aggressive invaders (Figueroa \& Castellanos 1988; Kantrud 1996; Kittelson \& Boyd 1997; Castillo et al. 2000) that, together with $S$. alterniflora, can monopolize habitats, whether physically stressful or more benign. Under the local conditions of the low and mid marshes, which favour meso-oligohaline species and weaken the deterministic role of intertidal elevation on flooding stress, none of the three species can be defined as competitively subordinate or dominant. We therefore concur with Emery et al. (2001) that salt marsh stress tolerators can also be good competitors.

The predictably of an environmental stress is a dominant factor for specialization (Jefferies et al. 1979; Davy et al. 2000) and for establishment/maintenance of a competitive hierarchy (with dominant and subordinate species) (Keddy 1989). The occurrence of a particular situation every day and distinct scenarios each year, means that local dominance at Patos Lagoon may be determined more by a lottery mechanism or by
Ecological Society, Journal of Ecology, 91, 951-965 
(C) 2003 British Ecological Society, Journal of Ecology, 91, 951-965 establishment of propagules and subsequent preemption of resources, than by stress tolerance and competition as in North Atlantic salt marshes (Bertness 1991a, 1991b, 1999). Although events occurring during the earliest establishment phases of the life history can be of primary importance in regulating plant species distribution along environmental gradients (Keddy 1989; Davy et al. 2000), seedlings and vegetative propagules of all three studied species are able to colonize low marsh mud flats (Kantrud 1996; Copertino et al. 1997; Kittelson \& Boyd 1997; Costa 1998; Castillo et al. 2000; Bortolus et al. 2002) and similar proportions of survivors of Spartina species (35-50\%) were observed 2 years after transplantation to southern Brazil mud flats (Costa \& Marangoni 1997). Alternative models considering the importance of founder effects on community structure in salt marshes have already been suggested by Bertness \& Ellison (1987), Scholten et al. (1987) and Levine et al. (1998) and their application to irregularly flooded salt marshes needs to be investigated. Additionally, as consumers can modify the competitive outcome by grazing local dominants or newly arrived migrants (Robertson 1991; Furbish \& Albano 1994; Taylor et al. 1997; Lee 1998), Chasmagnathus granulata could be an important determinant of the local dominance of $S$. maritimus or $S$. densiflora during simultaneous establishment with $S$. alterniflora, or secondary succession after disturbance in the low- and mid-salt marsh of the Patos Lagoon estuary. Further studies are necessary to test these hypotheses.

\section{Acknowledgements}

We would like to thank Anthony Davy, Paul Adam, Lindsay Haddon and the anonymous referees whose comments have greatly improved the manuscript. Mark Bertness and Bryan Silliman provided helpful comments on earlier drafts of the manuscript. The work was supported by CNPq (Brazilian Government) grants \#200470/88-4 PDE(C.S.B.C.),\#522124/94-1 (A.M.G.A.) and a post-graduation fellowship (J.C.M.).

\section{References}

Adam, P. (1993) Saltmarsh Ecology. Cambridge University Press, New York.

Allen, S.E., Grimshaw, H.M., Parkinson, J.A., Quarmby, C. \& Roberts, J.D. (1976) Chemical analysis. Methods in Plant Ecology (ed. S.B. Chapman), pp. 411-466. Blackwell Scientific, Oxford.

Baldwin, A.H. \& Mendelssohn, I.A. (1998) Effects of salinity and water level on coastal marshes: an experimental test of disturbance as a catalyst for vegetation change. Aquatic Botany, 61, 255-268.

Bertness, M.D. (1991a) Zonation of Spartina patens and Spartina alterniflora in a New England salt marsh. Ecology, 72, 138-148.

Bertness, M.D. (1991b) Interspecific interactions among high marsh perennials in a New England salt marsh. Ecology, 72, 125-137.

Bertness, M.D. (1999) The Ecology of Atlantic Shorelines. Sinauer Associates, Sunderland, Massachusetts.
Bertness, M.D. \& Callaway, R. (1994) Positive interactions in communities. Trends in Ecology and Evolution, 9, 191-193.

Bertness, M.D. \& Ellison, A.M. (1987) Determinants of pattern in a New England salt marsh plant community. Ecological Monographs, 57 (2), 129-147.

Bertness, M.D. \& Leonard, G.H. (1997) The role of positive interactions in communities: lessons from intertidal habitats. Ecology, 78, 1976-1989.

Bortolus, A. \& Iribarne, O. (1999) Effects of the SW Atlantic burrowing crab Chasmagnathus granulata on a Spartina salt marsh. Marine Ecology Progress Series, 178, 79-88.

Bortolus, A., Schwindt, E. \& Iribarne, O. (2002) Positive plantanimal interactions in the high marsh of an Argentinean coastal lagoon. Ecology, 83, 733-742.

Brower, J.E. \& Zar, J.H. (1977) Field and Laboratory Methods for General Ecology. Wm. C. Brown, Dubuque.

Burgers, G. (1999) The El Niño stochastic oscillator. Climate Dynamics, 15, 521-531.

Callaway, R.M. \& Pennings, S.C. (2000) Facilitation may buffer competitive effects: indirect and diffuse interactions among salt marsh plants. American Naturalist, 156 (4), $416-424$

Capitoli, R.R., Bemvenuti, C.E. \& Gianuca, N.M. (1977) Occurrence and bio-ecologic observations on Metasesarma rubripes crab in the estuarine region of Lagoa dos Patos. Atlântica (Rio Grande), 2 (1), 50-62.

Cargill, S.M. \& Jefferies, R.L. (1984) The effects of grazing by lesser snow geese on the vegetation of a sub-arctic salt marsh. Journal of Applied Ecology, 21, 669-686.

Castellanos, E.M., Figueroa, M.E. \& Davy, A.J. (1994) Nucleation and facilitation in saltmarsh succession: interactions between Spartina maritima and Arthrocnemum perenne. Journal of Ecology, 82, 239-248.

Castillo, J.M., Fernandez-Baco, L., Castellanos, E.M., Luque, C.J., Figueroa, M.E. \& Davy, A.J. (2000) Lower limits of Spartina densiflora and $S$. maritima in a Mediterranean salt marsh determined by different ecophysiological tolerances. Journal of Ecology, 88, 801-812.

Cavalieri, A.J. (1983) Proline and glycinebethaine accumulation by Spartina alterniflora Loisel. in response to $\mathrm{NaCl}$ and nitrogen in a controlled environment. Oecologia, 57, 20 24.

Christian, R.R., Bryant, W.L. Jr \& Brinson, M.M. (1990) Juncus roemerianus production and decomposition along gradients of salinity and hydroperiod. Marine Ecology Progress Series, 68, 137-145.

Coelho, C.A.S., Uvo, C.B. \& Ambrizzi, T. (2002) Exploring the impacts of the tropical Pacific SST on the precipitation patterns over South America during ENSO periods. Theoretical and Applied Climatology, 71, 185-197.

Copertino, M., Costa, C.S.B. \& Seeliger, U. (1997) Dinâmica populacional de Spartina alterniflora em pântanos salgados do estuário da Lagoa dos Patos, Rio Grande, RS. Annals of VIII Seminário Regional de Ecologia (ed. J.E. Santos), pp. 295-312. UFSCar/Programa de Pós-Graduação em Ecologia e Recursos Renováveis, São Carlos, Brazil.

Costa, C.S.B. (1997a) Tidal marshes and wetlands. Subtropical Convergence Environments: the Coast and Sea in the Warm-Temperate Southwestern Atlantic (eds U. Seeliger, C. Odebrecht \& J.P. Castello), pp. 24-26. Springer-Verlag, Berlin.

Costa, C.S.B. (1997b) Irregularly flooded marginal marshes. Subtropical Convergence Environments: the Coast and Sea in the Warm-Temperate Southwestern Atlantic (eds U. Seeliger, C. Odebrecht \& J.P. Castello), pp. 73-77. Springer-Verlag, Berlin.

Costa, C.S.B. (1998) Production ecology of Scirpus maritimus in southern Brazil. Ciência E Cultura (SBPC), 50 (4), $273-$ 280.

Costa, C.S.B. \& Marangoni, J.C. (1997) Criação de marismas com espécies nativas: experimento piloto no sul do Brasil. 
C. S. B. Costa J. C. Marangoni \& A. M. G. Azevedo
Annals of VII Congresso Latino Americano de Ciências Do Mar, Volume I (eds A.M. Paiva Filho \& R.R. Weber), pp. 200-201. Instituto Oceanográfico da Universidade de São Paulo/Associação Latino-americana de Investigadores em Ciências do Mar, Santos, Brazil.

Costa, C.S.B., Seeliger, U. \& Kinas, P.G. (1988) The effect of wind velocity and direction on the salinity regime in the lower Patos Lagoon estuary. Ciência E Cultura (SBPC), $\mathbf{4 0}$ (9), 909-912.

Costa, C.S.B., Seeliger, U., Oliveira, C.P.L. \& Mazo, A.M.M. (1997) Distribuição, funções e valores das marismas e pradarias submersas no estuário da Lagoa dos Patos (RS, Brasil). Atlântica (Rio Grande), 19, 67-85.

D’Incao, F., Silva, K.G., Ruffino, M.L. \& Braga, A.C. (1990) Hábito alimentar do caranguejo Chasmagnathus granulata Dana, 1851 na Barra do Rio Grande, RS (Decapoda, Grapsidae). Atlântica (Rio Grande), 12 (2), 85-93.

Daehler, C.C. \& Strong, D.R. (1995) Impact of high herbivore densities on introduced smooth cordgrass, Spartina alterniflora, invading San Francisco Bay, California. Estuaries, 18, 409-417.

Davy, A.J., Costa, C.S.B., Yallop, A.R., Proudfoot, A.M. \& Mohamed, M.F. (2000) Biotic interactions in plant communities of saltmarshes. British Saltmarshes (eds B.R. Sherwood, B.G. Gardiner \& T. Harris), pp. 109-127. Linnean Society of London, London.

Eleuterius, L.N. \& Eleuterius, C.K. (1979) Tide levels and salt marsh zonation. Bulletin of Marine Science, 29 (3), 394-400.

Emery, N.C., Ewanchuk, P.J. \& Bertness, M.D. (2001) Competition and salt-marsh plant zonation: stress tolerators may be dominant competitors. Ecology, 82, 2471-2485.

Figueroa, M.E. \& Castellanos, E.M. (1988) Vertical structure of Spartina maritima and Spartina densiflora in mediterranean marshes. Plant Form and Vegetation Structure (eds M.J.A. Werger, P.J.M. van der Aart, H.J. During \& J.T.A. Verhoeven), pp. 105-108. SPB Academic, The Hague.

Figueroa, M.E., Castillo, J.M., Redondo, S., Luque, T., Castellanos, E.M., Nieva, F.J. et al. (2003) Facilitated invasion by hybridization of Sarcocornia species in a salt-marsh succession. Journal of Ecology, 91, 616-626.

Furbish, C.E. \& Albano, M. (1994) Selective herbivory and plant community structure in a Mid-Atlantic salt marsh. Ecology, 75, 1015-1022.

Garcia, A.M., Vieira, J.P. \& Winemiller, K.O. (2001) Dynamics of shallow-water fish assemblage of the Patos Lagoon estuary (Brazil) during cold and warm ENSO episodes. Journal of Fish Biology, 59, 1218-1238.

Grace, J.B. (1995) On the measurement of plant competition intensity. Ecology, 76, 305-308.

Hacker, S.D. \& Bertness, M.D. (1999) Experimental evidence for the factors maintaining plant species diversity in a New England salt marsh. Ecology, 80, 2064-2073.

Holm, G.O. Jr, Sasser, C.E., Peterson, G.W. \& Swenson, E.M. (2000) Vertical movement and substrate characteristics of oligohaline marshes near a high-sediment, riverine system. Journal of Coastal Research, 16, 164-171.

Iribarne, O., Bortolus, A. \& Botto, F. (1997) Between-habitat differences in burrow characteristics and trophic modes in the southeastern Atlantic burrowing crab Chasmagnathus granulata. Marine Ecology Progress Series, 155, 137-145.

Jefferies, R.L. (1977) Growth responses of coastal halophytes to inorganic nitrogen. Journal of Ecology, 65, 847-865.

Jefferies, R.L., Davy, A.J. \& Rudmik, T. (1979) The growth strategies of coastal halophytes. Ecological Processes in Coastal Environments (eds R.L. Jefferies \& A.J. Davy), pp. 243-268. Blackwell Scientific, Oxford

Kantrud, H.A. (1996) The Alkali (Scirpus maritimus L.) and Saltmarsh (S. Robustus Pursh) Bulrushes: a Literature Review. Information and Technology Report 6. National Biological Service, Jamestown, North Dakota. http:// www.npwrc.usgs.gov/resource/literatr/bulrush/bulrush.htm (last update 16 July 1997).
Keddy, P.A. (1989) Competition. Chapman \& Hall, London.

Kittelson, P.M. \& Boyd, M.J. (1997) Mechanisms of expansion for an introduced species of cordgrass, Spartina densiflora, in Humboldt Bay, California. Estuaries, 20, 770-778.

Lee, S.Y. (1998) Ecological role of grapsid crabs in mangrove ecosystem: a review. Marine and Freshwater Research, 49, $335-343$.

Lessmann, J.M., Mendelssohn, I.A., Hester, M.W. \& McKee, K.L. (1997) Population variation in growth response to flooding of three marsh grasses. Ecological Engineering, 8, 31-47.

Levine, J.M., Brewer, J.S. \& Bertness, M.D. (1998) Nutrients, competition and plant zonation in a New England salt marsh. Journal of Ecology, 86, 285-292.

Lightfoot, D.C. \& Whitford, W.G. (1987) Variation in insect densities on desert creosotebush: is nitrogen a factor. Ecology, 68, 547-557.

Louda, S.M., Keeler, K.H. \& Holt, R.D. (1990) Herbivore influences on plant performance and competitive interactions. Perspectives on Plant Competition (eds J.B. Grace \& D. Tilman), pp. 414-444. Academic Press, San Diego.

Mendelssohn, I.A. (1979) The influence of nitrogen level, form, and application method on the growth response of Spartina alterniflora, North Carolina. Estuaries, 2 (2), 106-112.

Möller, O.O., Castaing, P., Dalomon, J. \& Lazure, P. (2001) The influence of local and non-local forcing effects on the subtidal circulation of Patos Lagoon. Estuaries, 24 (2), 297-311.

NOAA (2000) Climate of 1999 - Annual Review. National Climatic Data Center/NOAA Homepage, Asheville, North Carolina. http://lwf.ncdc.noaa.gov/oa/climate/research/ 1999/ann/ann99.html (last update 12 January 2000).

NOAA (2001) Climate of 2000 - Annual Review. National Climatic Data Center/ NOAA Homepage, Asheville, North Carolina. http://1wf.ncdc.noaa.gov/oa/climate/research/ 2000/ann/ann.html (last update 12 January 2001).

Odum, W.E. (1988) Comparative ecology of tidal freshwater and salt marshes. Annual Review of Ecology and Systematics, 19, 147-176.

Paludan, C. \& Morris, J.T. (1999) Distribution and speciation of phosphorus along a salinity gradient in intertidal marsh sediment. Biogeochemistry, 45, 197-221.

Parsons, K.A. \& de La Cruz, A. (1980) Energy flow and grazing behavior of concephaline grasshoppers in a Juncus roemerianus marsh. Ecology, 61, 1045-1050.

Pennings, S.C. \& Bertness, M.D. (1999) Using latitudinal variation to examine effects of climate on coastal salt marsh pattern and process. Current Topics in Wetland Biogeochemistry, 3, 100-111.

Pennings, S.C. \& Bertness, M.D. (2001) Salt marsh communities. Marine Community Ecology (eds M.D. Bertness, S.D. Gaines \& M.E. Hay), pp. 289-316. Sinauer Associates, Sunderland, Massachusetts.

Pennings, S.C. \& Callaway, R.M. (1992) Salt marsh plant zonation: the relative importance of competition and physical factors. Ecology, 73, 681-690.

Pennings, S.C., Carefoot, T.H., Siska, E.L., Chase, M.E. \& Page, T.A. (1998) Feeding preferences of a generalist saltmarsh crab: relative importance of multiple plant traits. Ecology, 79, 1968-1979.

Pennings, S.C. \& Moore, D.J. (2001) Zonation of shrubs in western Atlantic salt marshes. Oecologia, 126, 587-594.

Pennings, S.C., Selig, E.R., Houser, L.T. \& Bertness, M.D. (2003) Geographic variation in positive and negative interactions among salt marsh plants. Ecology, 84, 1527-1538.

Pielou, E.C. \& Routledge, R.D. (1976) Salt marsh vegetation: latitudinal gradients in the zonation patterns. Oecologia, 24, 311-321.

Podlejski, V. (1982) Phenology and seasonal above-ground biomass in two Scirpus maritimus marshes in the Camargue. Folia Geobotanica and Phytotaxonomica (Praha), 17, 225-236.
Journal of Ecology, 91, 951-965 
965

Irregularly flooded

marsh
Portnoy, J.W. \& Giblin, A.E. (1997) Effects of historic tidal restrictions on salt marsh sediment chemistry. Biogeochemistry, 36, 275-303.

Ranwell, D.S. (1974) The salt marsh to tidal woodland transition. Hydrobiological Bulletin (Amsterdam), 8, 139-151.

Robertson, A.I. (1991) Plant-animal interactions and the structure and function of mangrove forest ecosystems. Australian Journal of Ecology, 16, 433-443.

Rogel, J.A., Ariza, F.A. \& Silla, R.O. (2000) Soil salinity and moisture gradients and plant zonation in Mediterranean salt marshes of southeast Spain. Wetlands, 20, 357-372.

Rozema, J., Scholten, M.C.T., Blaauw, P.A. \& Diggelen, J. (1988) Distribution limits and physiological tolerances with particular reference to the salt marsh environment. Plant Population Ecology (eds A.J. Davy, M.J. Hutchings \& A.R. Watkinson), pp. 137-164. Blackwell Scientific, Oxford.

Russell, P.J., Flows, T.J.P. \& Hutchings, M.J. (1985) Comparison of niche breadths and overlaps of halophytes on salt marshes of differing diversity. Vegetatio, 61, 171-178.

Salisbury, F.B. \& Ross, C.W. (1992) Plant Physiology. Wadsworth, San Diego.

Santos, M. \& Almeida, S.L. (2000) Anatomia foliar de Spartina Schreber (Poaceae) da Ilha de Santa Catarina (Florianopolis, SC). Insula (Florianopolis), 29, 1-24.

Scholten, M., Blaauw, P.A., Stroetenga, M. \& Rozema, J. (1987) The impact of competitive interactions on the growth and distribution of plant species in salt marshes. Vegetation Between Land and Sea (eds A.H.L. Huiskes, C.W.P.M. Blom \& J. Rozema), pp. 270-281. Dr Junk Publishers, Dordrecht.

Seeliger, U. \& Costa, C.S.B. (2002) The Patos-Mirim basins, lagoons and estuary, south Brazil: natural and human forcing factors. South American Basins: Loicz Global Change Assessment and Synthesis of River Catchment-Coastal Sea Interaction and Human Dimensions. LOICZ Reports \& Studies 21 (eds L.D. Lacerda, H.H. Kremer, B. Kjerve, W. Salomons, J.I. Marshall \& C.J. Crossland), pp. 105-112. LOICZIPO, Texel, the Netherlands.

Seeliger, U., Costa, C.S.B. \& Abreu, P.C. (1997) Energy flow and habitats in the Patos Lagoon estuary. Subtropical Convergence Environments: the Coast and Sea in the WarmTemperate Southwestern Atlantic (eds U. Seeliger, C. Odebrecht \& J.P. Castello), pp. 65-70. Springer-Verlag, Berlin.

Siegel, S. (1975) Estatística Não-Paramétrica Para as Ciências Do Comportamento. McGraw-Hill, São Paulo.

Silliman, B.R. \& Bertness, M.D. (2002) A trophic cascade regulates salt marsh primary production. Proceedings of the National Academy of Sciences (USA), 99, 10500-10505.

Silliman, B.R. \& Zieman, J.C. (2001) Top-down control of Spartina alterniflora production by periwinkle grazing in a Virginia salt marsh. Ecology, 82, 2830-2845.
Silva, C.P., Pereira, C.M.P. \& Dorneles, L.P.P. (1993) Espécies de gramíneas e crescimento de Spartina densiflora Brong. em uma marisma da Laguna dos Patos, RS, Brasil. Caderno de Pesquisa, Série Botanica (Santa Cruz Do Sul), 5, 95108.

Snow, A.A. \& Vince, S.W. (1984) Plant zonation in an Alaskan salt marsh II: an experimental study of the role of edaphic conditions. Journal of Ecology, 72, 669-684.

Stewart, G.R., Larher, F., Ahmad, I. \& Lee, J.A. (1979) Nitrogen metabolism and salt-tolerance in higher plant halophytes. Ecological Processes in Coastal Environments (eds R.L. Jefferies \& A.J. Davy), pp. 211-227. Blackwell Scientific, Oxford.

Stout, J.P. (1984) The Ecology of Irregularly Flooded Salt Marshes of Northeastern Gulf of Mexico: a Community Profile. Biological Report 85(7.1). Fish and Wildlife Service Minerals Management Service/US Department of Interior, Washington.

Taylor, K.L., Grace, J.B. \& Marx, B.D. (1997) The effects of herbivory on neighbour interactions along a coastal marsh gradient. American Journal of Botany, 84, 709-715.

Vince, S.W. \& Snow, A.A. (1984) Plant zonation in an Alaskan salt marsh. I. Distribution, abundance, and environmental factors. Journal of Ecology, 72, 651-667.

Wang, F.C. (1997) Dynamics of intertidal marshes near shallow estuaries in Lousiana. Wetlands Ecology and Management, 5, 131-143.

van Wijnen, H.J. \& Bakker, J.P. (1999) Nitrogen and phosphorus limitation in a coastal barrier salt marsh: the implications for vegetation succession. Journal of Ecology, 87, 265-272.

Williams, A.C. \& McCarthy, B.C. (2001) A new index of interspecific competition for replacement and additive designs. Ecological Research, 16, 29-40.

Wolcott, D.L. \& O'Connor, N.J. (1992) Herbivory in crabs: adaptations and ecological considerations. American Zoologist, 32, 370-381.

Zar, J.H. (1984) Biostatistical Analysis. Prentice Hall, Englewood Cliffs, New York.

Zedler, J.B., Callaway, J.C., Desmond, J.S., Vivian-Smith, G., Williams, G.D., Sullivan, G. et al. (1999) Californian saltmarsh vegetation: an improved model of spatial pattern. Ecosystems, 2, 19-35.

Zhou, J. \& Lau, K.M. (2001) Principal modes of interannual and decadal variability of summer rainfall over South America. International Journal of Climatology, 21, 16231644.

Received 13 August 2002

revision accepted 21 May 2003
(C) 2003 British Ecological Society, Journal of Ecology, 91, 951-965 